\title{
Virtual Class Solusi Pembelajaran Daring Terpadu di Masa Pandemi Pada SMA Wijaya Putra Surabaya
}

\author{
Surya Priyambudi ${ }^{1}$, Yulis Setyowati ${ }^{2}$, M. Harist Murdani ${ }^{3}$ \\ ${ }^{123}$ Universitas Wijaya Putra \\ surya@uwp.ac.id, yulissetyowati@uwp.ac.id, muhammadharist@uwp.ac.id
}

\begin{abstract}
Abstrak
Mitra pengabdian kepada masyarakat adalah SMA Wijaya Putra Surabaya. Permasalahan Mitra, yaitu: 1)Guru belum memaksimalkan penggunaan materi digital; 2)Guru mengalami kebingungan mengelolah perangkat pembelajaran daring; 3)Siswa mengalami kebingungan belajar karena berbagai aplikasi pembelajaran daring yang dipergunakan guru; 4)Pimpinan sekolah tidak dapat memonitoring kegiatan belajar karena aplikasi pembelajaran daring yang dipergunakan berbeda-beda. Metode menyelesaikan masalah, yaitu: 1)Pelatihan dan pendampingan Guru pembuatan materi digital pada aplikasi pembelajaran; 2)Pembuatan aplikasi LMS berupa Virtual Class untuk pembelajaran daring; 3)Pelatihan dan pendampingan Guru dan Siswa dalam penggunaan aplikasi Virtual Class untuk pembelajaran daring; 4)Pelatihan dan pendampingan Pimpinan Sekolah dalam memonitoring pembelajaran daring aplikasi Virtual Class. Pelaksanaan program, yaitu: 1)Melakukan koordinasi dengan mitra dalam perancangan materi digital dan storyboard aplikasi Virtual Class; 2)Pelatihan dan pendampingan pembuatan materi digital menggunakan aplikasi Power Point, Kinemaster, dan Google; 3)Pembuatan LMS berupa aplikasi Virtual Class; 4)Pelatihan dan pendampingan aplikasi Virtual Class bagi guru dan siswa; 5)Pelatihan dan pendampingan pimpinan sekolah dalam memonitoring pembelajaran daring aplikasi Virtual Class. Evaluasi kegiatan dilakukan setiap selesai pelatihan dan pendampingan serta keberlanjutan dilakukan minimal 2 bulan sekali dalam 1 tahun setelah program selesai dilakukan. Diharapkan SMA di Surabaya yang memiliki permasalahan tentang media pembelajaran dapat diberikan Training of Trainers oleh SMA Wijaya Putra Surabaya.
\end{abstract}

Kata Kunci : Pembelajaran Daring, Learning Management System, Virtual Class, Sekolah Menengah Atas.

\section{PENDAHULUAN}

Pemilihan mitra pada Pengabdian Kepada Masyarakat didasarkan hasil observasi yang dilakukan oleh Tim Pengusul, yang kualifikasinya menurut Tim Pengusul dipandang memenuhi syarat sesuai Panduan Penelitian dan Pengabdian kepada Masyarakat Universitas Wijaya Putra Tahun 2021. Adapun mitra yang menjadi mitra Pengabdian Kepada Masyarakat (PKM) ini adalah Sekolah Menengah Atas di Kota Surabaya bagian barat yang berlokasi pada kecamatan Pakal, ada sebanyak 140 Sekolah Menengah Atas yang berada di Kota Surabaya (Kementerian Pendidikan Budaya, 2020), salah satunya adalah SMA Wijaya Putra yang beralamatkan di Jl. Raya Benowo No 1-3 Kota Surabaya.

Survei Kementerian Pendidikan dan Kebudayaan menunjukkan bahwa 98\% sekolah menengah atas (SMA) menerapkan metode pembelajaran daring selama pandemi Covid-19, 
sehingga kondisi pandemi memaksa Lembaga Pendidikan menyelenggarakan mayoritas kegiatan belajar mengajar lewat daring. Seperti yang telah disampaikan oleh Keengwe \& Georgina dalam penelitiannya telah menyatakan bahwa perkembangan teknologi memberikan perubahan terhadap pelaksanaan pengajaran dan pembelajaran (Keengwe, J., \& Georgina, D., 2012). Teknologi informasi dapat diterima sebagai media dalam melakukan proses pendidikan, termasuk membantu proses belajar mengajar, yang juga melibatkan pencarian referensi dan sumber informasi (Wekke, I. S., \& Hamid, S., 2013).

Sarana dan prasarana yang dimiliki SMA Wijaya Putra sudah cukup baik karena memiliki fasilitas teknologi informasi yang berupa laboratorium komputer, wifi internet, laboratorium MIPA, dan laboratorium praktikum lainnya. Sarana pembelajaran yang sudah terpenuhi untuk meningkatkan prestasi belajar siswa, namun pada masa pandemi Covid-19 saat ini semua pembelajaran dilakukan secara daring sehingga tidak dapat melakukan pembelajaran di sekolah namun melakukan proses pembelajaran dan penugasan di tempat tinggalnya masing-masing.

Berdasarkan pengamatan lapangan yang dilakukan oleh tim pengusul terhadap mitra yaitu SMA Wijaya Putra dirasa perlu dilakukan pendampingan terhadap guru dalam melakukan proses pembelajaran daring yang terpadu. Di masa pandemi covid-19 saat ini proses belajar mengajar dilakukan secara daring tanpa tatap muka secara langsung, sehingga belum terbiasanya guru memberikan pembelajaran terhadap siswa secara daring. Oleh karena itu tim pengusul akan melakukan pelatihan dan pendampingan terhadap guru dan siswa dalam melakukan pembelajaran daring secara terpadu agar pimpinan sekolah dapat mengetahui proses belajar mengajar secara daring berjalan dengan lancar.
Pimpinan kepala sekolah SMA Wijaya Putra dijabat oleh Bapak Andri Priyono, S.Pd., M.Si. sejak tahun 2020 hingga sekarang. Jumlah siswa pada saat ini telah mencapai 359 siswa dengan rincian laki-laki 136 dan perempuan 223 siswa. Jumlah Guru saat ini 17 orang dan Tenaga Pendidik sebanyak 3 orang. SMA Wijaya Putra adalah salah satu dari beberapa Sekolah Menengah Atas di Kota Surabaya yang mampu menyediakan fasilitas internet secara penuh dan non-stop, fasilitas ini ditujukan sebagai sarana penunjang proses belajar

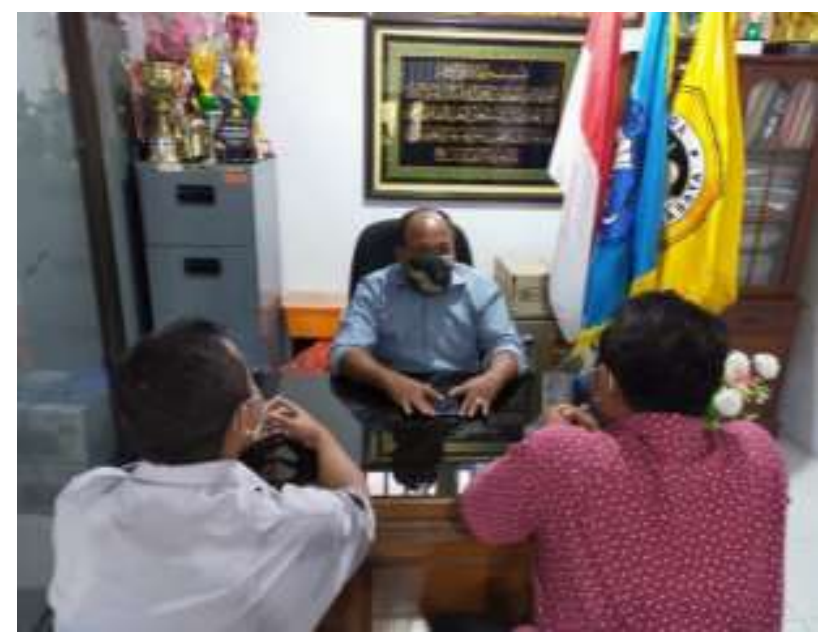

mengajar untuk para guru di lingkungan sekolah. Selain koneksi internet, SMA Wijaya Putra juga memiliki ruang laboratorium komputer yang memadai. Namun sayangnya, keuntungan dari adanya fasilitas-fasilitas ini kurang bisa dimanfaatkan secara maksimal oleh oleh Guru dalam pembuatan materi pembelajaran digital yang dipergunakan dalam pembelajaran daring saat ini. Berikut adalah foto dari sekolah SMA Wijaya Putra:

Gambar 1. Tim PKM Bersama Kepala Sekolah SMA Wijaya Putra Surabaya 


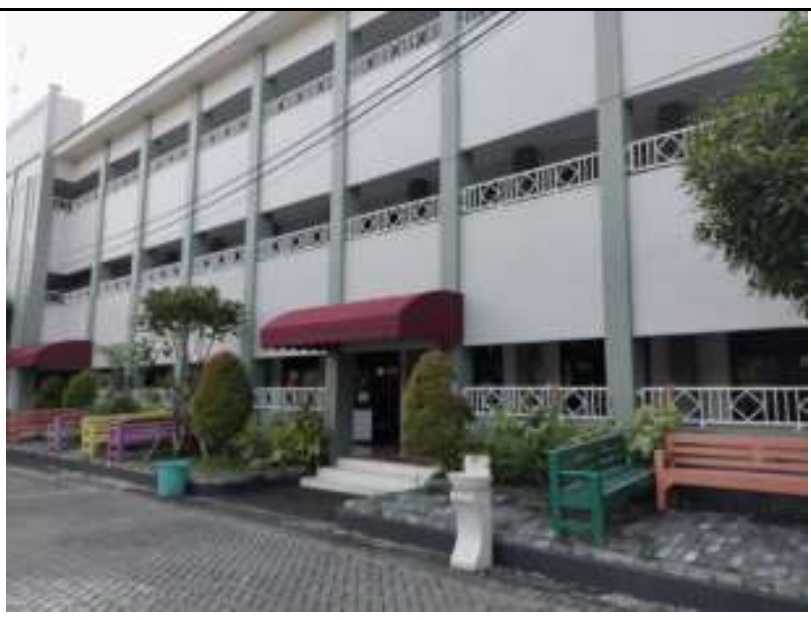

Gambar 2. Lingkungan Sekolah SMA Wijaya Putra Surabaya

SMA Wijaya Putra merupakan salah satu sekolah yang telah menerapkan proses belajar mengajar secara daring, namun pelaksanaan belajar mengajar secara daring belum sepenuhnya optimal dikarenakan aplikasi yang dipergunakan bukan termasuk kategori Learning Management System, oleh karena itu perlu adanya aplikasi pembelajaran daring yang menggunakan Learning Management System sehingga mempermudah guru dan siswa dalam berinteraksi saat berlangsungnya proses belajar mengajar secara daring dan pimpinan sekolah dapat mengetahui proses pengajaran yang dilakukan oleh guru.

\section{Learning Management System (LMS)} merupakan suatu aplikasi yang berbasis opensource sehingga Tim PKM dapat membuatkannya dan mengembangkannya hingga dapat digunakan untuk mengelola pembelajaran daring pada SMA Wijaya Putra, LMS yang baik akan meliputi beberapa aspek yaitu: materi, penempatan, pengelolaan, dan penilaian (Mahnegar, F., 2012). Beberapa fitur dimiliki LMS yang dapat mendukung proses pembelaran daring, yaitu: forum diskusi, kurikulum sumber belajar, kuis, tugas, jenis informasi akademik, dan pengelolaan data siswa. Ada beberapa jenis LMS yang dapat dimanfaatkan dalam proses pembelajaran, yaitu: Schoology, Learnboos, Edmoso, Moodle, Blackboard, WebCT dan lain-lain (Dwiyogo, D., 2018). Oleh karena itu perlu dilakukan proses pembelajaran daring yang memadai dari sisi LMS, materi pelajaran, dan tugas. Dengan kata lain pemilihan LMS sebisa mungkin mudah dipergunakan, materi pelajaran yang bersifat inovatif yang mengutamakan audio visual, dan pemberian tugas yang bersifat tidak memberatkan siswa, sehingga tidak mengalami bosan dalam proses pembelajaran daring tersebut.

Dalam pembuatan materi ajar ada beberapa Guru yang belum memaksimalkan penggunaan media digital sehingga proses belajar mengajar daring tidak sepenuhnya maksimal. Diperlukan adanya inovasi pemberian materi ajar yang digital supaya pada proses pembelajaran siswa tidak mengalami bosan hanya membaca materi berupa text format pdf ataupun docx saja. Diperlukan berbagai materi ajar digital yang berupa animasi, video, dan gambar yang dapat tersimpan pada aplikasi media pembelajaran daring agar setiap saat siswa dapat membuka materi digital tersebut.

Saat ini Guru SMA Wijaya Putra dalam melakukan pelaksanaan proses pembelajaran daring menggunakan media pembelajaran daring yang berbeda-beda sehingga siswa mengalami kebingungan dalam menjalankan proses pembelajaran daring tersebut. Adapun beberapa media pembelajaran daring yang dipergunakan meliputi; Whatssapp Group, Facebook, Google Classroom, Twitter, dan sebagainya. Peran Guru sebagai tenaga pendidik sangatlah penting sebagai salah satu faktor dalam menjamin kualitas dan mutu pembelajaran, karena Guru yang akan secara langsung berinteraksi dengan siswa.

Aplikasi pembelajaran daring yang dipergunakan oleh Guru tidak termasuk kategori Learning Management System serta banyak aplikasi media pembelajaran daring yang dipergunakan dalam proses belajar mengajar sehingga siswa mengalami kebingungan dalam melakukan aktifitas belajar. Guru juga masih mengalami kebingungan dalam mengelolah perangkat pembelajaran, pemberian nilai, absensi, pemberian tugas, video conference dsb, dikarenakan aplikasi pembelajaran daring yang dipergunakan tidak termasuk kategori Learning Management System. Pimpinan sekolah mengalami kesulitan dalam memonitoring dan 
memantau proses pembelajaran daring yang dilakukan oleh Guru dan siswa karena berbagai macam aplikasi pembelajaran daring yang dipergunakan oleh Guru untuk menyampaikan materi dan tugas kepada siswa. Melalui wawancara terhadap guru bahwa selama pembelajaran daring berlangsung untuk motivasi belajar siswa menurun, karena hanya sedikit yang berpartisipasi dan aktif dalam pembelajaran daring sehingga perlu adanya penggunaan aplikasi dan media pembelajaran daring yang inovatif dan terpusat. Mengingat urgensi proses pembelajaran daring menjadi sangat penting saat kondisi pandemi Covid19, maka sosialisasi pemanfaatan aplikasi media belajar daring kepada guru dan siswa perlu ditingkatkan. Sosialisasi ini terutama untuk memfasilitasi proses pembelajaran yang belum terpapar dengan teknologi pendidikan.

Program PKM ini merupakan kelanjutan dari hasil penelitian yang pernah dilakukan oleh tim, sebagaimana telah dipublikasikan pada jurnal Pendidikan lintang songo, volume 2 no 2, tahun 2019 tentang pembelajaran menggunakan Learning Management System untuk meningkatkan efektivitas belajar siswa (Surya, Priyambudi. 2019) dan juga dipublikasikan pada jurnal internasional pada Journal of Education and Practice, volume 11 no 31, tahun 2020 dengan judul The Development of E-Learning Model for College Students in the Industrial Era 4.0 (Surya, Priyambudi. 2019).

\section{METODE}

Tim PKM melakukan pelatihan dan pendampingan terhadap pimpinan sekolah, guru, dan siswa sehingga bertujuan untuk memberikan keterampilan bagi mitra dalam menyiapkan materi dan menggunakan aplikasi Virtual Class untuk belajar mengajar secara daring. Berikut dijelaskan teknologi yang dipergunakan dalam upaya produksi media pembelajaran daring dan panduan penggunaannya. Proses perancangan materi ajar serta aplikasi media pembelajaran daring yang dilakukan oleh tim dan mitra, produksi materi ajar oleh tim serta aplikasi media pembelajaran daring oleh mitra, panduan penggunaan aplikasi pembelajaran daring oleh tim, dan penerapan menggunakan aplikasi media pembelajaran daring yang telah diisi materi berbasis digital oleh guru, untuk alur pelaksanaan tersebut dapat digambarkan sebagai berikut.

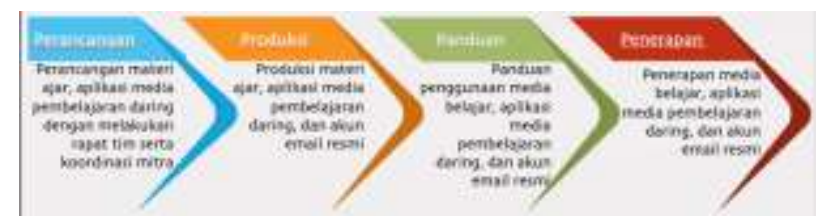

Gambar 3. Alur Pelaksanaan Virtual Class

Adapun permasalahan yang menjadi prioritas untuk diselesaikan dan metode pelaksanaannya sebagaimana dijelaskan dalam tabel berikut ini:

Tabel 1. Metode Pelaksanaan

\begin{tabular}{|c|c|c|c|}
\hline No & Permasalahan & $\begin{array}{c}\text { Metode } \\
\text { Pelaksanaan }\end{array}$ & Keterangan \\
\hline \multirow[t]{2}{*}{1} & \multirow[t]{2}{*}{$\begin{array}{l}\text { Guru belum } \\
\text { memaksimalka } \\
\text { n penggunaan } \\
\text { media } \\
\text { pembelajaran } \\
\text { digital untuk } \\
\text { pembuatan } \\
\text { materi ajar. }\end{array}$} & \multirow[t]{2}{*}{$\begin{array}{l}\text { Pelatihan dan } \\
\text { pendampinga } \\
\text { n Guru } \\
\text { pembuatan } \\
\text { materi digital } \\
\text { pada aplikasi } \\
\text { pembelajaran } \\
\text { - }\end{array}$} & $\begin{array}{l}\text { Terdapat } \\
\text { materi ajar } \\
\text { animasi } \\
\text { menggunaka } \\
\text { n media } \\
\text { Microsoft } \\
\text { Power Point } \\
\text { yang sudah } \\
\text { terupload } \\
\text { pada aplikasi } \\
\text { media } \\
\text { pembelajaran } \\
\text { daring. }\end{array}$ \\
\hline & & & $\begin{array}{l}\text { Terdapat } \\
\text { materi ajar } \\
\text { video } \\
\text { menggunaka } \\
\text { n media } \\
\text { Kinemaster } \\
\text { yang sudah } \\
\text { terupload } \\
\text { pada aplikasi } \\
\text { media } \\
\text { pembelajaran }\end{array}$ \\
\hline
\end{tabular}




\begin{tabular}{|c|c|c|c|}
\hline & & & daring. \\
\hline & & & $\begin{array}{l}\text { Terdapat } \\
\text { materi ajar } \\
\text { menggunaka } \\
\mathrm{n} \text { aplikasi } \\
\text { google } \\
\text { sekolah yang } \\
\text { terupload } \\
\text { pada aplikasi } \\
\text { media } \\
\text { pembelajaran } \\
\text { daring. }\end{array}$ \\
\hline 2 & $\begin{array}{l}\text { Aplikasi media } \\
\text { pembelajaran } \\
\text { daring yang } \\
\text { dipergunakan } \\
\text { masih belum } \\
\text { interaktif. }\end{array}$ & $\begin{array}{l}\text { Pembuatan } \\
\text { aplikasi LMS } \\
\text { berupa } \\
\text { Virtual Class } \\
\text { untuk } \\
\text { pembelajaran } \\
\text { daring }\end{array}$ & $\begin{array}{l}\text { Terdapat } \\
\text { aplikasi } \\
\text { Virtual Class } \\
\text { yang sudah } \\
\text { dilengkapi } \\
\text { dengan } \\
\text { berbagai } \\
\text { menu seperti; } \\
\text { modul materi } \\
\text { (file pptx, } \\
\text { docx, excelx, } \\
\text { pdf, video, } \\
\text { dsb), soal, } \\
\text { kuis, absensi, } \\
\text { video } \\
\text { conference, } \\
\text { chatting, } \\
\text { pesan, forum, } \\
\text { polling, dll } \\
\text { untuk proses } \\
\text { pembelajaran } \\
\text { daring yang } \\
\text { lebih } \\
\text { interaktif } \\
\text { untuk Guru } \\
\text { dan siswa } \\
\text { yang dapat } \\
\text { diakses } 24 \\
\text { jam }\end{array}$ \\
\hline 3 & $\begin{array}{l}\text { Guru dan siswa } \\
\text { masih } \\
\text { menggunakan } \\
\text { berbagai } \\
\text { macam aplikasi }\end{array}$ & $\begin{array}{l}\text { Pelatihan dan } \\
\text { pendampinga } \\
\mathrm{n} \text { guru dan } \\
\text { siswa dalam } \\
\text { penggunaan }\end{array}$ & $\begin{array}{l}\text { Terdapat } \\
\text { panduan } \\
\text { penggunaan } \\
\text { aplikasi } \\
\text { Virtual } \\
\end{array}$ \\
\hline
\end{tabular}

\begin{tabular}{|c|c|c|c|}
\hline & \multirow[t]{2}{*}{$\begin{array}{l}\text { media } \\
\text { pembelajaran } \\
\text { daring untuk } \\
\text { proses belajar } \\
\text { mengajar. }\end{array}$} & \multirow{2}{*}{$\begin{array}{l}\text { aplikasi } \\
\text { Virtual Class } \\
\text { untuk } \\
\text { pembelajaran } \\
\text { daring }\end{array}$} & $\begin{array}{l}\text { Classs bagi } \\
\text { guru untuk } \\
\text { pembelajaran } \\
\text { daring. }\end{array}$ \\
\hline & & & $\begin{array}{l}\text { Terdapat } \\
\text { panduan } \\
\text { penggunaan } \\
\text { aplikasi } \\
\text { Virtual } \\
\text { Classs bagi } \\
\text { siswa untuk } \\
\text { pembelajaran } \\
\text { daring. }\end{array}$ \\
\hline 4 & $\begin{array}{l}\text { Pimpinan } \\
\text { sekolah tidak } \\
\text { dapat } \\
\text { melakukan } \\
\text { monitoring dan } \\
\text { evaluasi saat } \\
\text { proses kegiatan } \\
\text { pembelajaran } \\
\text { daring } \\
\text { berlangsung. }\end{array}$ & $\begin{array}{l}\text { Pelatihan dan } \\
\text { pendampinga } \\
\text { n Pimpinan } \\
\text { Sekolah } \\
\text { dalam } \\
\text { memonitorin } \\
\text { g } \\
\text { pembelajaran } \\
\text { daring } \\
\text { aplikasi } \\
\text { Virtual Class }\end{array}$ & $\begin{array}{l}\text { Terdapat role } \\
\text { menu } \\
\text { pimpinan } \\
\text { sekolah pada } \\
\text { aplikasi } \\
\text { Virtual Class } \\
\text { untuk } \\
\text { memonitorin } \\
\text { g dan } \\
\text { mengevaluasi } \\
\text { proses } \\
\text { pembelajaran } \\
\text { daring yang } \\
\text { dilakukan } \\
\text { oleh Guru } \\
\text { dan siswa. }\end{array}$ \\
\hline
\end{tabular}

Evaluasi pelaksanaan program dilakukan setiap selesai kegiatan yang dijadwalkan dengan diskusi pada mitra yang terkait. Evaluasi dilakukan berdasarkan ketercapaian target luaran dari masingmasing program prioritas yang sudah diagendakan. Setiap pihak secara terbuka wajib menyampaikan apa yang dirasakan, terutama jika dirasa kurang memahami terhadap materi pelatihan tersebut. Pada saat pendampingan, mitra harus selalu aktif untuk menggunakan semua yang sudah diberikan dan bertanya jika terdapat masalah. Evaluasi akhir kegiatan dilakukan melalui rapat bersama dengan mitra sekolah guna mengetahui seberapa besar dampak program dan apa saja yang masih perlu diperbaiki. 


\section{HASIL DAN PEMBAHASAN}

Kegiatan program kemitraan masyarakat ini bertujuan untuk memberikan solusi terhadap sekolah mitra dengan cara melakukan pelatihan dan pendampingan IPTEK berbasis ICT untuk pembelajaran daring kepada guru dalam rangka meningkatkan keterampilan. Sejalan dengan era pandemi covid-19 saat ini, kemampuan mengajar melalui aplikasi pembelajaran daring perlu dikuasai oleh guru agar materi tersampaikan dengan baik. Pembelajaran daring dalam literasi era masa kini masuk ke dalam informasi digital atau ketersambungan manusia sejagat yang memudahkan manusia dalam bekerja. Tujuan dalam kegiatan ini merupakan pelatihan dan pendampingan pada pembuatan serta penggunaan media pembelajaran digital yang dipergunakan dalam pembelajaran daring yang terpusat oleh guru dan siswa sehingga dapat di monitoring oleh pimpinan sekolah pada SMA Wijaya Putra Surabaya. Dalam pelaksanaan kegiatan ini Tim melakukan pelatihan dan pendampingan menjadi 5 (lima) tahap, yaitu: 1)Melakukan koordinasi dengan pimpinan sekolah dan guru dalam perancangan materi digital dan storyboard aplikasi Virtual Class; 2)Pelatihan dan pendampingan terhadap guru dalam pembuatan materi digital menggunakan aplikasi Power Point, Kinemaster, dan Google; 3)Pembuatan LMS berupa aplikasi Virtual Class; 4)Pelatihan dan pendampingan aplikasi Virtual Class bagi guru dan siswa; 5)Pelatihan dan pendampingan terhadap pimpinan sekolah dalam memonitoring pembelajaran daring aplikasi Virtual Class.

Kesehatan yang harus tetap dijaga pada saat pandemi covid-19 melanda dunia hingga saat ini sehingga menjadikan beberapa kebijakan berubah drastis. Seperti kebijakan di dunia pendidikan, yang akan menggunakan sistem baru. Prinsip utama dalam pembelajaran di tahun ajaran 2020/2021 yakni kesehatan dan keselamatan siswa dan tenaga pendidikan, maka pembelajaran jarak jauh akan menjadi solusinya. Dengan proses pembelajaran daring siswa diharapkan bisa belajar dari rumah dan guru bisa mendampingi proses pembelajaran daring tersebut.
Keterbatasan guru dalam memberikan penjelasan pembelajaran maupun memberikan kesempatan kepada siswa menggali informasi lebih banyak menjadi terbatasi jika semua dapat dilakukan di dalam kelas saja. Aplikasi pembelajaran daring dapat menjembatani hal tersebut, dengan catatan guru maupun siswa memiliki wawasan yang sama dalam penggunaan aplikasi pembelajaran daring. Oleh sebab itu sangatlah menjadi penting melakukan persamaan persepsi dan persamaan kemampuan penggunaan aplikasi pembelajaran daring sehingga guru dapat memanfaatkan pembelajaran daring untuk penunjang pembelajaran di kelas, dan siswa memahami bagaimana menggali informasi sebanyakbanyaknya melalui pemanfaatan aplikasi pembelajaran daring pada proses pembelajaran seperti halnya pembelajaran di kelas.

Aplikasi media pembelajaran daring yang dipergunakan merupakan aplikasi moodle yang telah dimodifikasi menjadi Virtual Class oleh tim sehingga diharapkan aplikasi media pembelajaran daring ini mirip kelas belajar seperti halnya pembelajaran di dalam kelas, adapun penggunaan aplikasi video conference yang bisa dipergunakan didalam aplikasi Virtual Class ini seperti aplikasi zoom, aplikasi google meet, aplikasi big blue button, aplikasi jitsi, aplikasi microsoft teams, dan aplikasi webex. Untuk pemberian materi yang dilakukan oleh guru terhadap siswa juga dapat melalui format file aplikasi documents, aplikasi slide, aplikasi sheet, aplikasi pdf, aplikasi video, aplikasi audio, dan lain sebagainya. Pada menu penugasan melalui aplikasi moodle juga terdapat menu quiz, survey, dan assignmet. Sebagai sarana komunikasi antara guru kepada siswa dan siswa kepada siswa lainnya maka tersedia menu pada aplikasi Virtual Class yaitu chat dan forum. Jika guru ingin memberikan absensi terhadap siswa yang mengikuti pembelajaran daring maka juga disediakan menu attendance pada aplikasi Virtual Class.

Dengan menerapkan protokol Kesehatan dan komunikasi melalui media zoom dan pertemuan di kelas pada kegiatan pelatihan dan pendampingan dimulai pada bulan Juni sampai September 2021. Kegiatan pelatihan dilaksanakan setiap hari Kamis dengan melibatkan 2 Mahasiswa dari Universitas 
Wijaya Putra. Adapun pelatihan dan pendampingan dilakukan pada pukul 12.00-15.00 WIB. Pasrtisipasi mitra dalam program ini sangatlah aktif dikarenakan aplikasi yang dipergunakan sangatlah baru dan menarik sehingga kegiatan Pengabdian Kepada Masyarakat dapat berjalan sesuai yang diharapkan. Aplikasi Virtual Class yang beralamatkan pada situs https://smawp.vclass.id merupakan aplikasi berbasis web dan mobile sehingga dapat dipergunakan diberbagai macam SmartPhone dan $P C$.

Pada kegiatan pelatihan dan pendampingan menggunakan aplikasi pembelajaran daring Virtual Class. Kegiatan ini diawali dengan menyajikan tampilan layar awal pembuka aplikasi pembelajaran daring Virtual Class. Menjelaskan setiap bagian yang terdapat pada layar utama. Kemudian guru maupun siswa diberikan pengarahan dalam menjalankan aplikasi pembelajaran daring Virtual Class, setiap peserta melakukannya secara mandiri dan diberikan pengarahan oleh pemateri jika terdapat kesulitan. Dalam pelaksanakan pelatihan dan pendampingan tersebut dalam terlihat pada gambar berikut ini:

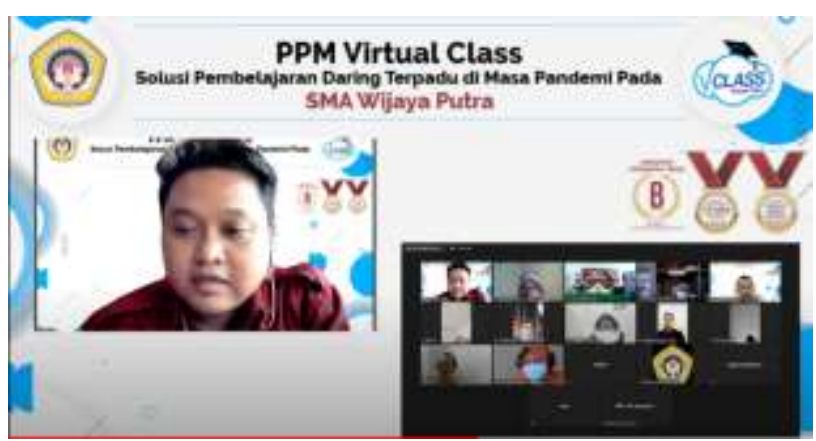

Gambar 3. Pendampingan dan Pelatihan Via Zoom

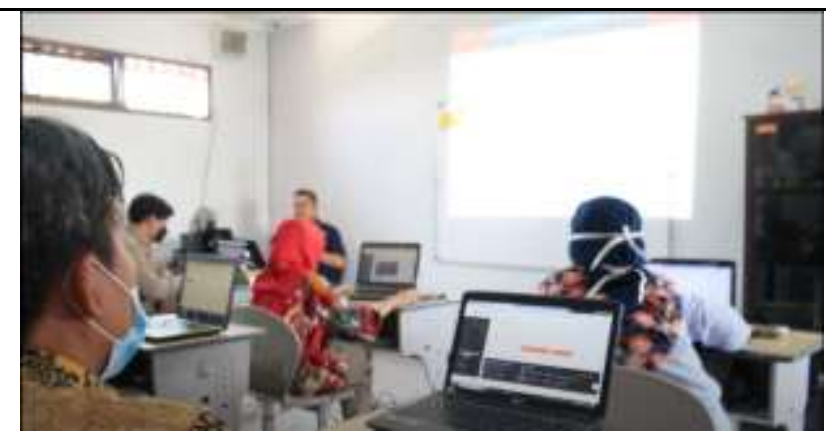

Gambar 4. Pendampingan dan Pelatihan di Kelas

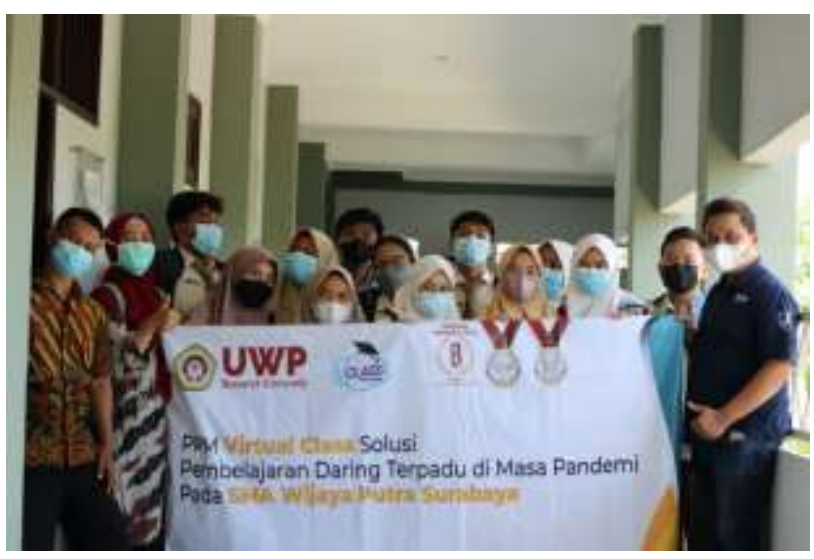

Gambar 5. Pendampingan dan Pelatihan di Kelas

Saat pelaksanaan pembelajaran secara daring sangat memerlukan media pembelajaran yang tepat untuk menunjang keberhasilan proses pembelajaran guru dan siswa. Selain itu interaksi guru dengan siswa, dan evaluasi pembelajaran juga menunjang proses pembelajaran daring. Selain itu siswa cukup antusias dalam belajar ketika menggunakan media pembelajaran daring dengan aplikasi Virtual Class. Dalam kegiatan yang terlaksana ini untuk perlakuan yang dilakukan terhadap guru dan siswa berupa penggunaan media pembelajaran daring berupa aplikasi Virtual Class. Untuk tampilan awal media pembelajaran daring menggunakan aplikasi Virtual Class yang sudah dikembangkan dapat dipaparkan pada gambar berikut ini, halaman login berfungsi untuk pengguna pimpinan sekolah, guru, dan siswa sehingga dapat masuk kedalam aplikasi pembelajaran daring Virtual Class dengan cara menginputkan username 
dan password, tampilan halaman login dapat dilihat pada gambar 6 berikut ini.

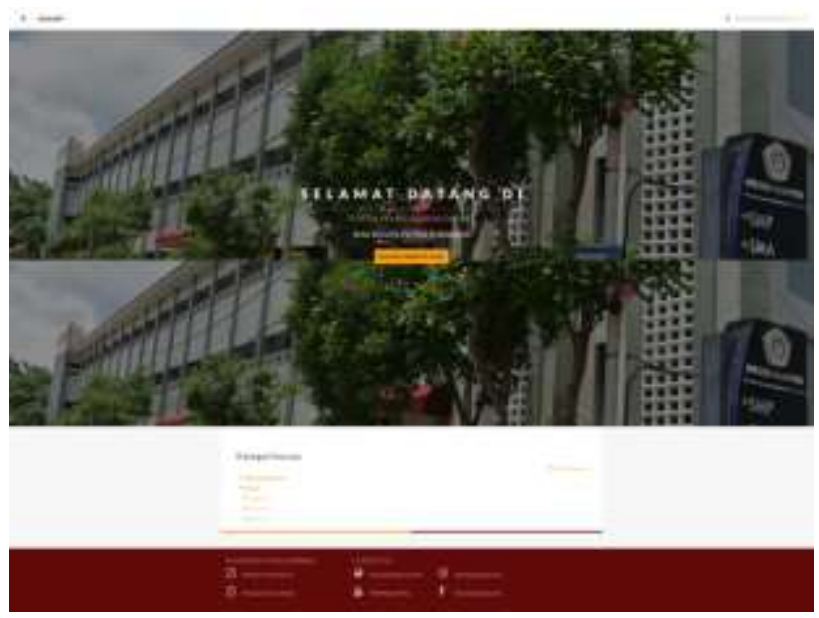

Gambar 6. Tampilan Awal VCLASS

Halaman menu pada guru dan siswa menampilkan mata pelajaran kelas belajar yang diampu dan aplikasi video conference yang bisa dipergunakan didalam aplikasi Virtual Class ini seperti aplikasi zoom, aplikasi google meet, aplikasi big blue button, aplikasi jitsi, aplikasi microsoft teams, dan aplikasi webex. Untuk pemberian materi yang dilakukan oleh guru terhadap siswa juga dapat melalui format file aplikasi documents, aplikasi slide, aplikasi sheet, aplikasi pdf, aplikasi video, aplikasi audio, dan lain sebagainya. Pada menu penugasan melalui aplikasi moodle juga terdapat menu quiz, survey, dan assignmet, tampilan halaman login dapat dilihat pada gambar 7 dan 8 .

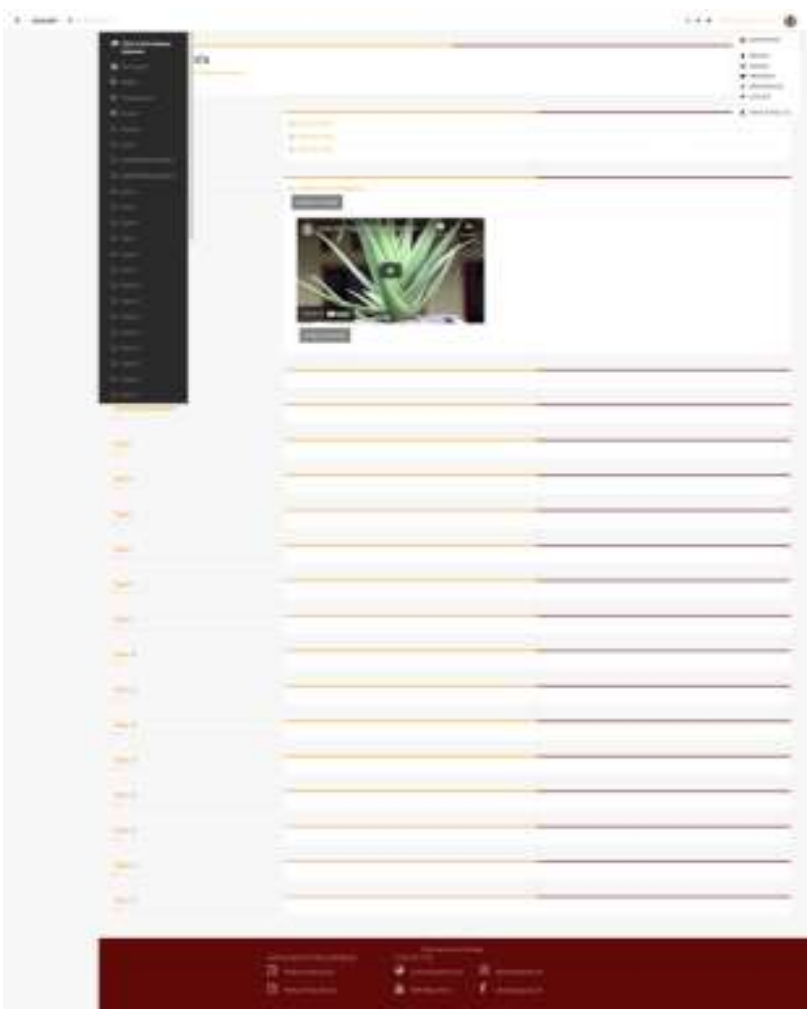

Gambar 7. Tampilan Menu Guru

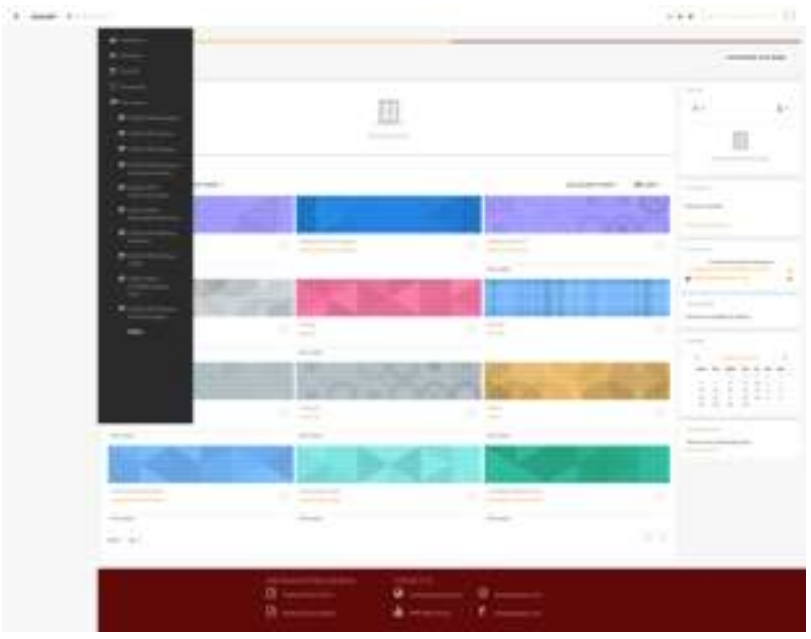

Gambar 8. Tampilan Menu Siswa

Halaman menu pada pimpinan sekolah dapat mengecek dan melihat kelas mata pelajaran seluruh guru dan siswa yang melakukan pembelajaran daring, sehingga pimpinan sekolah dapat memonitoring pelaksanaan proses 
pembelajaran daring yang dilakukan oleh guru dan siswa, untuk tampilan menu pimpinan sekolah pada aplikasi pembelajaran daring dapat dilihat pada gambar 9 berikut ini.

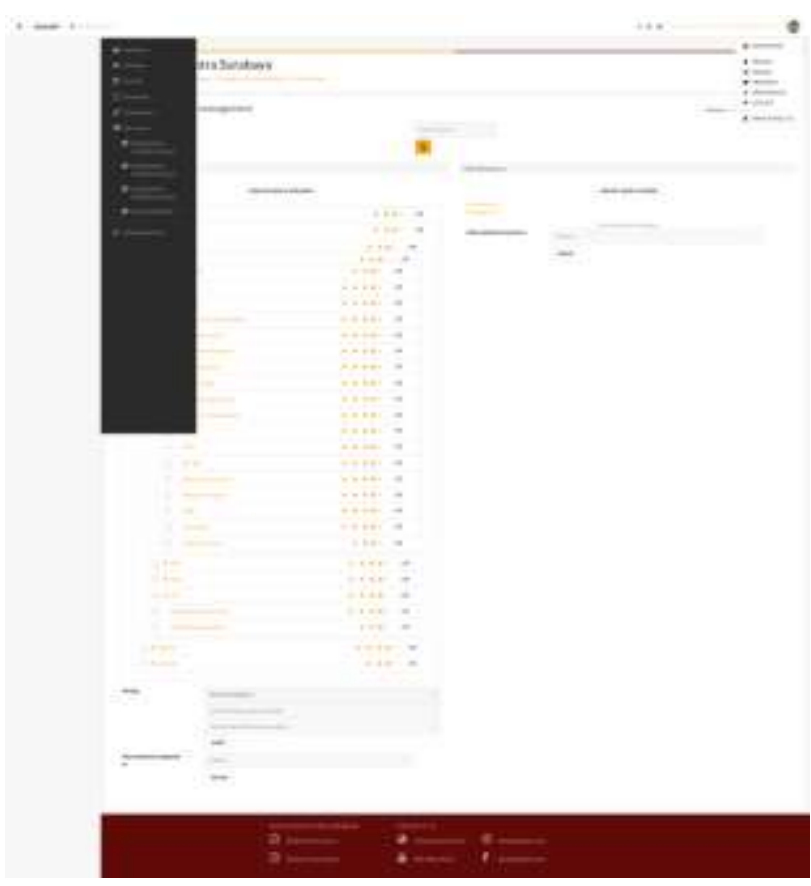

Gambar 9. Tampilan Menu Pimpinan Sekolah

Berdasarkan hasil kegiatan dalam pelatihan dan pendampingan pembuatan materi ajar berbasis digital dan penggunaan media pembelajaran daring menggunakan aplikasi Virtual Class, maka diperoleh: 1)memiliki aplikasi Virtual Class yang beralamatkan pada situs https://smawp.vclass.id; 2)terdapat peningkatan pemahaman pentingnya teknologi digital terhadap pembuatan materi ajar yang inovatif; 3)meningkatnya kemampuan dalam pengelolaan teknologi internet dalam pembelajaran daring menggunakan aplikasi Virtual Class; 4)Meningkatnya semangat belajar siswa dapat dilihat keaktifan siswa dalam pembelajaran daring menggunakan aplikasi Virtual Class; 5)Meningkatnya kemampuan dalam memonitoring pembelajaran digital terpusat menggunakan aplikasi Virtual Class.

Melalui evaluasi dapat diidentifikasi bahwa pelatihan menggunakan aplikasi pembelajaran daring Virtual Class memberikan hasil yang baik, karena mitra terlihat antusias dan konsisten mengikuti pelatihan dari hari ke hari. Dari pengamatan yang dilakukan selama kegiatan berlangsung, baik pada saat menyajikan materi teori maupun praktik, tingkat keaktifan mitra sangatlah tinggi karena dapat dilihat dari aktifnya absensi serta jurnal kelas guru dan siswa tiap harinya, hasil belajar siswa pun juga mengalamai peningkatan sehingga dapat dilihat dari nilai tugas dan ulangan yang diberikan oleh guru dengan menggunakan aplikasi pembelajaran daring Virtual Class.

Potensi keberlanjutan Pengabdian Kepada Masyarakat ini dapat dilihat dari tercapainya pelaksanaan penggunaan aplikasi pembelajaran daring Virtual Class berhasil dengan baik. Diharapkan dapat dilakukan tindak lanjut oleh sekolah guna memelihara kompetensi awal bagi guru dan siswa dalam mengimplekentasikan di dalam aplikasi pembelajaran daring Virtual Class, sehingga pembelajaran efektif dan efisien dapat terwujud lebih baik lagi. Setelah dilaksanakannya kegiatan pengabdian tentang penggunaan aplikasi pembelajaran daring Virtual Class tersebut diharapkan dapat membentuk sistem pembelajaran yang fleksibel tanpa mengurangi alokasi waktu pembelajaran yang telah diterapkan, serta aktivitas guru diluar sekolah pun dapat berjalan sebagaimana mestinya. Bagi para siswa yang terkendala jaringan internet pun masih dapat mengikuti materi pembelajaran sebagaimana mestinya.

\section{KESIMPULAN}

Hampir secara keseluruhan untuk kegiatan pengabdian masyarakat sudah mempunyai dampak yang positif, yaitu 1)memiliki aplikasi Virtual Class yang beralamatkan pada situs https://smawp.vclass.id; $\quad$ 2)meningkatnya 
pemahaman penggunaan teknologi digital dalam pembuatan materi ajar; 3)meningkatnya kemampuan dalam pengelolaan teknologi internet dalam pembelajaran daring; 4)meningkatnya semangat belajar siswa sehingga dapat dilihat dalam keaktifan siswa mengikuti pembelajaran daring; dan 5)meningkatnya kemampuan dalam memonitoring pembelajaran digital yang terpusat.

Keberlanjutan program ini adalah tim pelaksana akan melalukan monitoring minimal 2 bulan sekali selama 1 tahun setelah program PKM selesai dilaksanakan, hal ini dilakukan semata-mata untuk mengetahui kekurangan atau kelebihan terhadap kegiatan yang telah dilakukan dalam rangka untuk menetapkan rekomendasi terhadap keberlangsungan atau pengembangan kegiatankegiatan berikutnya. Sekolah SMA Wijaya Putra bisa dikatakan mewakili populasi SMA yang berada di Kota Surabaya bagian barat yang memiliki permasalahan berkaitan tentang media pembelajaran yang terpusat dan memiliki menu yang interaktif, sehingga nantinya dapat memberikan Training of Trainers terhadap SMA di daerah Kota Surabaya yang berdekatan dengan lokasi SMA Wijaya Putra serta diharapkan dapat meningkatkan hasil belajar siswa SMA.

\section{UCAPAN TERIMAKASIH (Bila ada)}

Dalam kesempatan ini kami menyampaikan terima kasih yang mendalam kepada Universitas Wijaya Putra yang telah memberikan dukungan secara meterial dan non material atas terselenggaranya kegiatan ini. Demikian juga terhadap Pimpinan, Guru, dan Siswa SMA Wijaya Putra Kota Surabaya atas partisipasinya dalam mengikuti program dari awal sampai akhir. Semoga kedepannya kegiatan ini bisa dilaksanakan jauh lebih baik.

\section{REFERENSI}

Dwiyogo, D. (2018). Pembelajaran Berbasis Blended Learning. Depok: Rajawali Pers.
Emda, Amna. (2018). "Kedudukan motivasi belajar siswa dalam pembelajaran. " Lantanida Journal 5, No. 2: 172-182.

Keengwe, J., \& Georgina, D. (2012). The digital course training workshop for online learning and teaching. Education and Information Technologies, 17(4),: 365-379. https://doi.org/10.1007/s10639-011-9164-x.

Kementerian Pendidikan Budaya, "SMK HIDAYATUL UMMAH,” 2020. [Online]. Available: https://dapo.kemdikbud.go.id/sp/2/056000. [Accessed: 15-Maret-2021].

Mahnegar, F. (2012). Learning Management System. International Journal of Business and Social Science, 3(12), 144-150Marsh, D. Bleanded learning: Creating Learning Opportunities for Language Learners. New York: Cambridge University Press.

Surya, Priyambudi. (2019). Pengembangan Model Pembelajaran E-Learning Berbasis Efront Pada Pelajaran Bahasa Indonesia Untuk Meningkatkan Efektifitas Belajar Siswa SMA Wijaya Putra Surabaya. Jurnal Pendidikan, Lintang Songo, 2, No. 2: 8594.

Surya, Priyambudi. (2020). The Development of ELearning Model for College Students in the Industrial Era 4.0. Journal of Education and Practice, 11, No. 31: 68-78.

Wekke, I. S., \& Hamid, S. (2013). Technology on Language Teaching and Learning: A Research on Indonesian Pesantren. Procedia - Social and Behavioral Sciences, 83,: 585589.

https://doi.org/10.1016/J.SBSPRO.2013.06. $\underline{111 .}$ 